Jurnal Pustaka Budaya. Vol. 5, No. 2, Juli 2018

Copyright (C) 2018, pISSN: 2355 -1186| eISSN: 2442 - 7799

Available Online at: https://journal.unilak.ac.id/index.php/pb

\title{
BAHASA MELAYU DAN MINANGKABAU \\ DALAM KHAZANAH NASKAH MINANGKABAU
}

\author{
Pramono*), M. Yusuf**), Herry Nur Hidayat*** ${ }^{* *}$ \\ Universiras Andalas, Padang, Indonesia \\ pramono@hum.unand.ac.id*) \\ myusuf@hum.unand.ac.id**) \\ herrynh@hum.unand.ac.id***) \\ Naskah diterima: ......; direvisi: ......; disetujui: .......
}

\begin{abstract}
Abstrak
Bahasa Minangkabau adalah bahasa lisan yang mulai membentuk variasi tertulis setelah masuknya Islam, menggunakan aksara Jawi (Arab Melayu). Aksara ini dikenal luas di Minangkabau pada abad ke-18. Dampaknya, banyak karya sastra lisan Minangkabau dituliskan. Oleh karena ditulis dengan Jawi, perbedaan antara naskah Minangkabau dengan Melayu sangat samar. Seringkali naskah-naskah yang diklasifikasikan sebagai naskah Minangkabau dapat dibaca di Minangkabau atau dalam bahasa Melayu. Kecenderungan orang Minangkabau menulis dalam bahasa Melayu karena orang Minangkabau menganggap bahasa Minangkabau tidak jauh berbeda dengan bahasa Melayu. Jadi, jika orang Minangkabau menggunakan katakata Minangkabau dalam bahasa Melayu, mereka berpikir bahwa mereka telah menggunakan kata-kata Melayu tanpa mencoba menemukan kata-kata yang lebih sesuai dalam bahasa Melayu. Uniknya, bagi pembaca Minangkabau, naskah yang ditulis dalam bahasa Jawi (bahasa Melayu), dapat dibaca dalam bahasa Minangkabau. Sebagai contoh, 'bermula' akan dibaca sebagai 'baramulo', 'bandar' sebagai /banda/, /bersama/ sebagai /basamo/, 'hidup' sebagai /hiduik/ dan seterusnya. Menariknya, dalam naskah yang sama, jika dibaca oleh orang Minangkabau dalam dialek yang berbeda, maka akan dibaca dalam dialek itu. Misalnya, kata 'pakan Sabtu' akan dibaca /pokan Sotu/ oleh orang Minangkabau dalam dialek Payakumbuh dan akan dibaca /pakan Sabtu/ dalam dialek Padang. Berangkat dari fenomena kebahasan tersebut, artikel ini akan membahas dinamika kebahasaan Melayu dan Minangkabau dalam manuskrip Minangkabau.
\end{abstract}

Kata kunci: bahasa Melayu, bahasa Minangkabau, Jawi, naskah, Minangkabau.

\footnotetext{
Abstract

Minangkabau language is an oral language that began to form a written variety after the incoming of Islam, using the Jawi (Perso-Arabic) scripts. This scripts is widely known in Minangkabau in the eighteenth century. As a result, many Minangkabau oral literary works are written down. Since it was written in Jawi, the distinction between the Minangkabau and the Malay
} 
manuscripts is very vague. Often manuscripts classified as Minangkabau manuscripts can be read either in Minangkabau or in Malay. The tendency of Minangkabau people to write in Malay is very active because Minangkabau people thought Minangkabau language is not much different from the Malay language. So, if the Minangkabau people use the Minangkabau words in Malay language, they thought that they have used the Malay words without having tried to find a words which more corresponding in Malay. Uniquely, for Minangkabau readers, even written in Jawi (Malay language), but will be read in Minangkabau language. For examples, 'bermula' will be read as 'baramulo', 'bandar' as /banda/, /bersama/ as /basamo/, 'hidup' as /hiduik/ and so on. Interestingly, in the same manuscript, if it is read by Minangkabau people in different dialects, it will be read in that dialects (in different sounds). For example, the words 'pakan Sabtu' will be read /pokan Sotu/ by the Minangkabau in Payakumbuh dialect and it will be read /pakan Sabtu/ by the Padang dialects. Departing from the linguistic phenomenon, this paper will discuss the dynamic of social aspec languages using Malay and Minangkabau language in Minangkabau manuscripts.

Keywords: Malay language, Minangkabau language, Jawi, manuscript, Minangkabau.

\section{Pendahuluan}

Penelitian dan inventarisasi yang dilakukan oleh sejumlah peneliti naskah Minangkabau menginformasikan bahwa naskah Minangkabau terdapat dalam jumlah yang sangat banyak. Naskah-naskah Minangkabau tersebut tidak hanya tersimpan dalam sejumlah koleksi di Sumatra Barat, tetapi juga tersimpan di luar wilayah tersebut, seperti di Jakarta, Belanda, Inggris, Jerman, Prancis, dan Malaysia. Sampai 2013, naskah Minangkabau yang berhasil didata berjumlah sekitar 1200-an; 300-an naskah di antaranya tersimpan di luar Sumatra Barat, seperti Jakarta, Belanda, Inggris, dan Jerman (Zuriati, 2007: 1) dan 900-an naskah masih tersimpan dalam koleksi perorangan dan dalam koleksi surau-surau di Minangkabau (Yusuf, 2006; Zuriati dan M. Yusuf, 2008; Pramono, 2010: 247-249; Tim Peneliti Naskah Minangkabau, 2011-2013). Informasi singkat tentang naskah-naskah Minangkabau yang berada di luar Sumatra Barat dapat diperoleh dari sejumlah katalogus yang disusun oleh $\mathrm{H}$. $\mathrm{H}$. Juynboll (1899), Ph. S van Ronkel (1909; 1921), Amir Sutaarga dkk. (1972), M. C. Ricklefs dan P. Voorhoeve (1977), Hj. Wan
Ali Hj. Wan Mamat (1985), Perpustakaan Negara Malaysia (1991; 1992; 1997), T. E. Behrend (1998), E. P. Wieringa (1998), dan Teuku Iskandar (1999). Artinya, para peneliti naskah Minangkabau mendapatkan gambaran awal tentang naskah-naskah di luar Minangkabau, karena termuat dalam banyak katalogus yang sudah dipublikasikan.

Kondisi yang berbeda terjadi pada naskah-naskah Minangkabau yang ada dalam berbagai koleksi di Minangkabau sendiri yang meliputi wilayah rantau dan darek 'darat'. Banyak usaha penyelamatan (digitalisasi) dan inventarisasi serta katalogisasi telah dilakukan oleh para peneliti dan kelompok peneliti naskah Minangkabau, seperti Tim Peneliti Kelompok Kajian Puitika, Fakultas Sastra Universitas Andalas, Padang, berkerja sama dengan The Centre for Documentation \& Area-Transcultural Studies (C-DATS), Tokyo University of Foreign Studies, Jepang (2003); Yusri Akhimuddin (2007); Zuriati dan M. Yusuf (2008); Irina Katkova dan Pramono (2008); Tim Peneliti Balai Bahasa Padang bekerja sama dengan Fakultas Sastra Unand (2009); Pramono (2009); dan 
Tim Peneliti C-DATS-TUFS, FIB-Unand, Manassa, dan Aceh (2011-2013). Dari banyak kegiatan penelitian itu, hanya satu hasil penelitian dan katalogisasi yang baru berhasil diterbitkan, yakni penelitian dan katalogisasi yang dilakukan oleh Tim Peneliti Kajian Poetika pada 2003. Hasil penelitian itu dapat dilihat dalam buku Katalogus Naskah dan Skriptorium Minangkabau yang dieditori oleh M. Yusuf dan diterbitkan pada 2006. Selain hasil penelitian itu, naskah-naskah yang telah dikatalogisasi oleh beberapa peneliti dan tim peneliti naskah seperti tersebut di atas belum diterbitkan. Dengan kata lain, banyak naskah yang telah diinventarisasi dan dikatalogisasi masih tersimpan dalam laporan-laporan penelitian yang bersifat tidak terbuka untuk umum.

Berdasarkan pada "pembacan umum" terhadap deskripsi naskahnya, naskahnaskah Minangkabau dapat dikelompokkan ke dalam tiga kelompok. Pertama, naskahnaskah "impor", yaitu naskah-naskah yang berasal dari luar wilayah Minangkabau. Bahkan, ia sangat mungkin berasal dari luar wilayah Nusantara. Dari segi fisiknya, naskah-naskah kuno yang ditulis dengan aksara Arab dan berbahasa Arab ini terlihat lebih rapi. Baris demi baris kalimat yang ada pada setiap halaman terlihat tertata rapi dan jumlah baris per halaman sangat konsisten, atau setidaknya, kurang bervariasi. Tulisan yang terdapat di dalam naskah-naskah jenis ini pun tampak sangat rapi, indah, menggunakan tinta hitam yang "tipis", menggunakan tinta merah sebagai rubrikasi, dan dijilid rapi dengan menggunakan kulit binatang sebagai sampul luar. Naskah-naskah yang dapat dimasukkan ke dalam kategori ini, biasanya, memuat teks Alquran, teks terjemahan Alquran dalam bahasa Arab, teks-teks yang berasal dari Kitab Fikih, Kitab Tauhid, Doadoa, Zikir, teks-teks Tasawuf, dan teks-teks yang berkenaan dengan Nahu dan Saraf. Biasanya, naskah-naskah kategori ini tidak memuat banyak teks pada setiap naskah. Marginalisasi yang ada di dalam naskah, pada umumnya, ditulis dengan rapi sebagai syarah.

Kedua, naskah-naskah "lokal", yakni naskah-naskah yang sangat mungkin ditulis atau disalin oleh ulama yang berasal dari wilayah Minangkabau, atau sekurangkurangnya dari wilayah Nusantara. Biasanya, naskah ini ditulis dengan kurang rapi. Tulisan dengan menggunakan tinta hitam terlihat lebih tebal dan tidak serapi atau seindah tulisan yang terdapat pada naskah-naskah "impor". Jumlah baris yang terdapat pada setiap halaman, biasanya, sangat bervariasi. Pada umumnya, naskahnaskah jenis ini tidak mengandung rubrikasi. Naskah-naskah ini juga memuat banyak marginalisasi dari guru atau pembacanya. Di dalam setiap naskah, biasanya, terdapat banyak teks. Aksara yang digunakan di dalam naskah-naskah "lokal" ini adalah aksara Arab dan aksara ArabMelayu. Bahasa yang digunakan adalah bahasa Arab dan disertai bahasa Melayu sebagai terjemahan. Kadangkala, naskahnaskah ini menggunakan bahasa Melayu, bahasa Melayu-Minangkabau, dan disertai oleh bahasa Arab sebagai dasar rujukan. Beberapa naskah juga memuat teks yang lebih tepat jika dibaca dengan menggunakan bahasa Minangkabau. Pada umumnya, naskah jenis ini berisi kumpulan risalah tauhid, kumpulan risalah fikih, nukilan kitab tauhid, kitab fikih, penjelasan yang berkenaan dengan persoalan tauhid, fikih dan tasawuf, kumpulan doa, penjelasan tentang tata bahasa Arab, hikayat, syair, kitab-kitab perobatan, azimat, catatan tentang ulama tertentu, dan cacatan ulama tertentu tentang dirinya dan tentang peristiwa-peristiwa tertentu.

Ketiga, naskah-naskah lokal merupakan karya yang disalin atau ditulis oleh syekh di surau tempat ditemukannya naskah-naskah itu. Berangkali, ia juga merupakan karya yang disalin atau ditulis 
oleh syekh surau tersebut sewaktu belajar di surau lainnya. Atau, ia merupakan naskah yang ditulis atau disalin oleh syekh yang berasal dari surau lain di Minangkabau. Atau, bahkan, ia berasal dari syekh, guru tarekat, atau ulama lain dari luar wilayah Minangkabau.

Dalam konteks kebahasaan, secara singkat dapat dikatakan bahwa naskahnaskah Minangkabau wujud dalam bahasa Arab, Melayu dan Minangkabau. Namun demikian, secara khusus, dalam artikel ini akan dibahas penggunaan bahasa Melayu dan Minangkabau dalam naskah-naskah Minangkabau. Pembahasan ini didasarkan pada alasan bahwa naskah-naskah "asli" Minangkabau banyak yang ditulis dalam bahasa Melayu dan Minangkabau atau kedua-duanya dalam satu naskah. Berbagai aspek kebahasaan (penggunaan bahasa Melayu [BM] dan Minangkabau [BMk]) dalam naskah-naskah Minangkabau menjadi fokus diskusi dalam artikel ini.

\section{Metode Penelitian}

Secara keseluruhan, studi ini merupakan kajian kepustakaan dengan metode penelitian kualitatif. Dalam pembahasannya digunakan dua pendekatan, yakni pendekatan filologi dan pendekatan linguistik. Pendekatan filologi digunakan untuk menyediakan teks terbaca bagi khalayak yang lebih luas. Naskah-naskah Minangkabau yang ditulis dalam aksara Jawi memerlukan pendekatan filologi untuk menghadirkan teks yang dapat dipahami oleh khalayak luas melalui penyuntingan teks. Adapun pendekatan linguistik digunakan untuk menganalisis aspek-aspek kebahasaan yang menyangkut fenomena penggunaan bahasa Melayu dan Minangkabau dalam naskah-naskah Minangkabau.

Pengumpulan data dalam studi ini digunakan teknik pengumpulan data meliputi studi kepustakaan dan kritik teks. Kata "kritik" itu sendiri bisa berarti "sikap menghakimi dalam menghadapi sesuatu' sehingga dapat berarti 'menempatkan sesuatu sewajarnya' atau 'memberikan evaluasi'. Jadi, kritik teks berarti 'menempatkan teks pada tempat yang sewajarnya, memberikan evaluasi terhadap teks'. Pada tahap inilah nantinya akan tersedia sebuah edisi atau suntingan teks naskah-naskah yang dijadikan bahan penelitian. Edisi teks atau sering dikenal dengan istilah suntingan teks adalah (upaya) menyusun suatu teks secara utuh setelah dilakukan pemurnian teks ke dalam sesuatu bahasa. Pemurnian teks adalah upaya untuk menentukan salah satu teks yang akan dipakai sebagai dasar transliterasi dan terjemahan. Adapun transliterasi itu sendiri adalah penggantian atau pengalihan huruf demi huruf dari abjad yang satu ke abjad yang lain, misalnya dari huruf Arab-Melayu ke huruf Latin.

Hasil suntingan teks tersebut akan dianalisis dengan pendekatan linguistik. Berbagai aspek dan fenomena penggunaan bahasa Melayu dan Minangkabau akan dideskripsikan dan dianalisis secara kualitatif.

\section{Hasil dan Pembahasan}

\section{Khazanah Naskah Koleksi Surau-Surau Tarekat}

Bahasa Minangkabau adalah bahasa lisan yang mulai membentuk ragam tulis setelah masuknya Islam, yakni dengan digunakannya aksara Jawi. Dari beberapa catatan sarjana, disebutkan bahwa aksara ini dikenal luas di Minangkabau pada abad ke-18. Dengan dikenalnya aksara tersebut, maka khasanah sastra lisan Minangkabau banyak dituliskan. Dan, kegiatan baca-tulis aksara Jawi tersebut masih berlangsung hingga saat ini, meskipun sudah jarang dilakukan.

Kecenderungan orang Minangkabau menulis dengan bahasa Melayu sangat dimungkinkan karena masyarakat Minangkabau merasa bahwa bahasa Minangkabau itu tidak banyak berbeda 
dengan bahasa Melayu, sehingga jika orang Minangkabau menggunakan kata bahasa Minangkabau dalam berbahasa Melayu, mereka merasa seperti telah menggunakan kata bahasa Melayu tanpa perlu berusaha mencari kata yang lebih sesuai dalam bahasa Melayu. Uniknya, meskipun ditulis dengan aksara Jawi (bahasa Melayu), namun akan terbaca menjadi bunyi bahasa Minangkabau oleh pembaca Minangkabau. Misalnya, tulisan 'bermula' akan terbaca /baramulo/, 'bandar' terbaca /banda/, /bersama/ terbaca /basamo/, 'hidup' terbaca /hiduik/ dan seterusnya.

Menariknya lagi, satu naskah yang sama, jika dibaca oleh masyarakat Minangkabau dengan dialek yang berbeda akan terbaca dengan bunyi yang berbeda pula. Misalnya, tulisan 'pekan sabtu' akan terbaca /pokan sotu/ oleh masyarakat Minangkabau dengan penutur dialek Payakumbuh dan akan terbaca /pakan sabtu/ oleh penutur dialek Padang. Berangkat dari fenomena kebahasaan tersebut, tulisan ini nantinya akan mencoba mengulas beberapa aspek sosial budaya masalah bahasa dalam tradisi pernaskahan di Minangkabau.

Dari beberapa naskah Minangkabau yang ditulis dengan aksara Jawi ditemukan fenomena kebahasaan tersebut di atas. Secara sederhana dapat dilihat pada Tabel 1 berikut ini.

Tabel 1. Penggunaan BM dan BMk dalam Naskah Minangkabau

\begin{tabular}{|c|c|c|c|}
\hline No. & $\begin{array}{c}\text { Tertulis } \\
\text { dalam } \\
\text { Naskah }\end{array}$ & $\begin{array}{c}\text { Dibaca } \\
\text { dalam } \\
\text { BM }\end{array}$ & $\begin{array}{c}\text { Dibaca } \\
\text { dalam } \\
\text { BMk }\end{array}$ \\
\hline 1. & Sربو & kerbau & kabau \\
\hline 2. & هيغگكل & tinggal & tingga \\
\hline 3. & hinggap & hinggok \\
\hline 4. & kapal & kapa \\
\hline 5. & buل & bunda & bundo \\
\hline
\end{tabular}

\begin{tabular}{|c|c|c|c|}
\hline 6. & تيغكل & tinggal & tingga \\
\hline 7. & امس & emas & ameh \\
\hline 8. & تيف & tiap & tiok \\
\hline 9. & اتس & atas & ateh \\
\hline 10. & دكنل & dikenal & dikana \\
\hline 11. & اكر & akar & aka \\
\hline 12. & تمفت & tempat & tampek \\
\hline 13. & امفت & empat & ampek \\
\hline 14. & سـبركت & si Berkat & si Barakaik \\
\hline 15. & سـل مت & selamat & salamek \\
\hline 16. & سمبيل & sambil & sambia \\
\hline 17. & كإِيل & kecil & kaciak \\
\hline 18. & ســـتوس & sedetus & sadatuih \\
\hline 19. & فولوت & pulut & puluik \\
\hline 20. & سـومور & sumur & sumua \\
\hline
\end{tabular}

Dalam sebuah artikelnya mengenai transkripsi teks-teks Minangkabau yang terdapat di dalam naskah-naskah yang menggunakan aksara Jawi, Junus (1959: 1415) mengungkapkan bahwa perbedaan antara naskah-naskah Minangkabau dengan naskah-naskah Melayu amat samar. Sering naskah yang digolongkan sebagai naskah Minangkabau dapat dibaca menurut BMk dan menurut BM.

Dalam konteks ini, Djamaris (1982: 347) berpendapat bahwa berdasarkan pendapat yang mengatakan perbedaan antara BMk dan BM terletak pad segi lafalnya, maka teks Tambo Minangkabau yang menggunakan BM pun dapat dibaca menurut cara BMk. Dalam studinya yang cukup luas mengenai Tambo Minangkabau, Djamaris (1991: 118) mengungkapkan bahwa teks-teks tambo yang menurutnya menggunakan BM banyak dipengaruhi oleh BMk. Karena itu, bahasa teks Tambo Minangkabau pantas dikatakan menggunakan Bahasa MelayuMinangkabau; nama yang pernah digunakan oleh Van der Toorn dalam kata 
pengantarnya untuk edisi Kaba Mandjau Ari (1891) dan Tjindoer Mato (1886).

Persoalan seperti yang dikemukakan di atas juga dihadapi oleh Muhardi di dalam studinya mengenai Kaba si Tungga. Dengan mempertimbangkan bahwa teks Kaba si Tungga adalah karya anggota masyarakat Minangkabau tentang aspek kebudayaan Minangkabau, dan agar mudah dimengerti oleh pembaca (Minangkabau); Muhardi pada akhirnya memutuskan untuk mengalihaksarakan teks ini ke dalam BMk.

Pertimbangan lain yang digunakannya untuk mengalihaksarakan teks Kaba si Tungga ke BMk adalah tingkat kemudahannya, yaitu 71 persen. Artinya, 71 persen kata-kata di dalam teks ini tidak mengalami hambatan untuk dialihaksarakan ke BMk. Kalau ditransliterasikan ke BM, kata-kata yang tidak mengalami hambatan hanya mencapai 61,7 persen. Akan tetapi, di dalam hal itu Muhardi juga mengemukakan bahwa dia harus menyesuaikan lafal dan mengubah bentuk secara total dari BM ke BMk. Hal itu dilakukannya karena teks-teks kaba si Tungga yang menggunakan aksara Latin jelas-jelas mengacu ke BM. Sementara itu dia juga mengemukakan bahwa BMk yang digunakannya sebagai hasil penyesuaian dari BM adalah BMk yang tidak baku (Muhardi, 1986 : 91-114).

Dalam kenyataannya, antara BM dan BMk memang mempunyai hubungan kekerabatan yang sangat erat. Dari segi fonetik, pada BMk dan BM dapat dicatat halhal berikut ini ini.

1. Keduanya mempunyai vocal yang sama, tetapi dengan catatan sebagai berikut :

a. Vokal /ê/ yang terdapat pada suku kata awal dalam BM sepadan dengan vocal /a/ dalam BMk. Kata beban, ketan, emas, dan lepas dalam BM, sepadan dengan baban, katan, ameh, dan lapeh dalam BMk. b. Pada umumnya vocal /a/ pada akhir kata BM sepadan dengan vocal /o/ dalam BMk. Sebagai contoh, kata luka, bunda, kuda, dan tiba dalam BM, sepadan dengan luko, bundo, kudo, dan tibo dalam BMk.

c. Sering bunyi /-al/ dan /-ar/ pada akhir kata BM sepadan dengan vocal /a/ pada akhir kata BMk. Misalnya kata kepal/kapal, kabar, dan bantal sepadan dengan kapa, kaba, tuka, dan banta.

2. Di dalam BM terdapat tiga diftong, yaitu /ai/, /au/, dan /oi/. BMk, di samping memiliki ketiga diftong itu, juga mempunyai tiga diftong yang lain, yaitu /ia/, /ua/, dan /ui/. Dalam hal ini, hubungan yang terjadi antara BMk dan BM adalah sebagai berikut :

a. /ia/ berpadanan dengan /-il/, /ir/, /-er/, dan /-ar/ pada suku kata terakhir BM. Di samping itu juga berpadanan dengan vocal /i/ dan /e/ pada suku kata terakhir yang ditutup dengan /k/, /h/, dan /ng/

b. /ua/ berpadanan dengan /-ol/, /-ul/, /-or/, dan /-ur/ pada suku kata terakhir BM. Di samping itu juga berpadanan dengan vocal /u/ dan /o/ pada suku kata terakhir yang ditutup dengan $/ \mathrm{k} /$, /h/, dan /ng/

c. /ui/ berpadanan dengan /-up/, /-ub/, /-ut/, /-ud/, dan /-us/ pada suku kata terakhir BM.

3. Konsonan BMk seimbang dengan konsonan BM, dengan catatan bahwa konsonan /f/. /z/ dan konsonan gabungan /kh/ seta /sy/ hanya terdapat pada kata-kata pinjaman, misalnya fakie (fakir), azan, akhlak dan syawal. Konsonan /p/, /b/, /t/, dan /d/ pada posisi 
terakhir dalam BM berpadanan dengan /k/ dalam BMk. Contoh yang dapat dikemukakan di sini adalah tutup, lembab, ikut, dan sujud dalam BM berpadanan dengan tutuik, lambok, ikuik, dan sujuik dalam BMk. Di samping halhal di atas, vocal /s/ pada suku kata terakhir BM sepadan dengan vokal /h/ dalam BMk, misalnya lepas, emas dalam BM, dalam BMk adalah lapeh, dan ameh.

Dalam segi morfologi, hal-hal yang perlu dikemukakan I sini adalah yang berkenaan dengan awalan $\{$ ter- $\}$, \{ber- $\}$ dan akhiran \{-nya\}. Hal-hal itu adalah sebagai berikut :

1. Awalan \{ter-\} dalam BM sepadan dengan $\{$ ta- $\}$ dalam BMk, misalnya tergenang, terpijak, dan terjatuh dalam BM, dalam BMk masingmasing adalah taganang, tapijak, dan tajatuah.

2. Awalan $\{$ ber- $\}$ dalam BM sepadan dengan $\{\mathrm{ba}-\}$ dalam BMk, misalnya berkata, bergurau dan berguru dalam BM, dalam BMk masingmasing adalah bakato, bagurau, dan baguru. Perlu pula dikemukakan di sini bahwa \{ber-\} dalam BM dan \{ba-\} da;a, BMk terkadang digunakan dalam bentuk pasif. Kata-kata berpakaian dan berbunuh dalam BM, atau bapakai dan babunuah dalam BMk berarti dipakai dan dibunuh. Penggunaan awalan \{ber-\} di dalam teks-teks tambo Minangkabau yang menggunakan BM, oleh Edwar Djamaris (1982: 349) dianggap sebagai bentuk khusus di dalam teks tambo dan hal ini disebabkan adanya pengaruh bahasa Minangkabau. Di dalam Hikayat
Aceh (Iskandar, 1958 : 14), Hikayat Muhammad Hanafiyah (Brakel, 1975: 36), dan di dalam uraian Van der Toorn (1899: 93-94), sebagaimana juga dikutip oleh Djamaris (1982 : 349-350), gejala pemakaian bentuk pasif seperti itu juga terjadi. Roolvink (1965: 333) dalam Djamaris (1982: 350, 1991: 197) menyimpulkan bahwa di dalam BM klasik, penggunaan awalan \{ber-\} dalam bentuk pasif

\begin{tabular}{|c|c|c|}
\hline $\begin{array}{l}\text { Awalan } \\
\mathrm{e}\end{array}$ & $\begin{array}{l}\text { Penyebaran } \\
\text { dalam BMk }\end{array}$ & $\begin{array}{c}\text { Padanan dalam } \\
\text { BM }\end{array}$ \\
\hline $\begin{array}{ll}\mathrm{r} & \text { ta } \\
\mathrm{u} & \\
\mathrm{p} & \\
\mathrm{a} & \mathrm{ba} \\
\mathrm{k} & \\
\mathrm{a} & \\
\mathrm{n} & \\
& \\
\mathrm{s} & \end{array}$ & $\begin{array}{l}\text { taganang } \\
\text { tapijak } \\
\text { tajatuah } \\
\text { bajalan } \\
\text { bakato } \\
\text { baimbau } \\
\text { bapakai }\end{array}$ & $\begin{array}{l}\text { tergenang } \\
\text { terpijak } \\
\text { terjatuh } \\
\text { berjalan } \\
\text { berkata } \\
\text { berhimbau } \\
\text { (dihimbau) } \\
\text { berpakai } \\
\text { (dipakai) }\end{array}$ \\
\hline \multicolumn{3}{|l|}{ Akhiran } \\
\hline $\begin{array}{cc}\mathrm{a} & \text { nyo } \\
\mathrm{t} & \text { no } \\
\mathrm{u} & \mathrm{e} \\
& \mathrm{a} \\
\mathrm{h} & \mathrm{o}\end{array}$ & $\begin{array}{l}\text { rumahnyo } \\
\text { rumano } \\
\text { rumae } \\
\text { rumaa } \\
\text { rumao }\end{array}$ & $\begin{array}{l}\text { rumahnya } \\
\text { rumahnya } \\
\text { rumahnya } \\
\text { rumahnya } \\
\text { rumahnya }\end{array}$ \\
\hline
\end{tabular}

l yang tidak asing. Dalam bahasa BMk penggunaan bentuk itu juga merupakan hal yang biasa.

3. Akhiran $\{$-nya $\}$ dalam BM sering sepadan dengan $\{$-nyo $\}$ dalam BMk. Dalam beberapa dialek BMk, sering pula akhiran ini menjadi $\{-\mathrm{e}\},\{-\mathrm{a}\},\{-$ o\}, dan $\{$-no $\}$. kata rumahnya dalam BM, sepadan dengan rumahnyo, rumahe, sumao, rumaa, dan rumano (Cf. Junus, 1959 ; Roesli, 1967 ; Medan 1981). 
Untuk lebih memperjelas pembicaraan di atas, dapat dilihat Tabel 2, 3, dan 4 berikut ini.

Tabel 2. Contoh Penyebaran Vokal Khusus Bahasa Minangkabau

\begin{tabular}{|c|c|c|}
\hline Vokal & $\begin{array}{l}\text { Penyebaran } \\
\text { dalam BMk }\end{array}$ & $\begin{array}{c}\text { Padanan } \\
\text { dalam BM }\end{array}$ \\
\hline $\mathrm{e}$ & $\begin{array}{l}\text { kuek } \\
\text { galeh }\end{array}$ & $\begin{array}{l}\text { kuat } \\
\text { gelas }\end{array}$ \\
\hline o & luko & luka \\
\hline & $\begin{array}{l}\text { kudo } \\
\text { dad } o\end{array}$ & $\begin{array}{l}\text { kuda } \\
\text { dada }\end{array}$ \\
\hline $\mathrm{a}$ & baban & beban \\
\hline & katam & ketam \\
\hline & $\mathrm{kapa}$ & kepal, kapal \\
\hline & $\begin{array}{l}\text { kaba } \\
\text { tuka }\end{array}$ & $\begin{array}{l}\text { kabar } \\
\text { tukar }\end{array}$ \\
\hline
\end{tabular}

Tabel 3. Contoh Penyebaran Diftong Khusus Bahasa Minangkabau

\section{Tabel 4. Contoh Penyebaran Morfem} Khusus dalam BMk

Dualisme keterbacaan teks-teks susastra Minangkabau yang menggunakan aksara Arab-Melayu ini paling tidak disebabkan oleh dua faktor utama. Faktor yang pertama, seperti yang diungkapkan oleh Tamsin Medan (1981 : 22), adalah bahwa BMk tidak mempunyai tradisi tulisan - seharusnya, tradisi tulisan yang dimiliki oleh masyarakat ini dapat dikatan relatif baru. Pengenalan terhadap tradisi ini sejalan

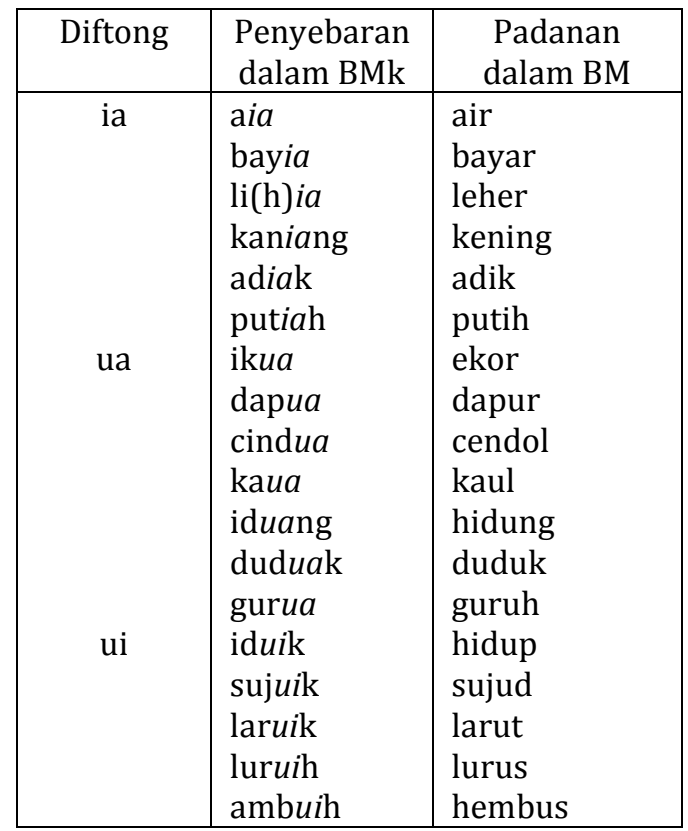

dengan pengenalan terhadap BM melalui ejaan Arab-Melayu. Oleh karena itu, dalam bahasa tulis, masyarakat Minangkabau cenderung menggunakan BM (sekarang Bahasa Indonesia).

Sehubungan dengan hal di atas, patut pula dikemukakan di sini pendapat Van der Toorn (1899 : xvi), bahwa aksara yang digunakan oleh masyarakat Minangkabau dalam bahasa tulis mereka adalah aksara yang digunakan di dalam BM Riau, dan ejaan yang digunakan juga demikian sebagai berikut.

De letterteekens, die de Minangkabauer voor zijn schrijftaal bezigt, zijn dezelfde als in het Riausch; evenzo is de spelling der woorden in hoofdzaak die, welke voor het laatsgenoemde dialect gevolgd wordt.

Kecenderungan orang Minangkabau menulis dengan BM disebabkan oleh beberapa hal. Pertama, BM secara sepintas kelihatannya hanya sedikit berbeda dengan BMk, yaitu berbeda dalam ucapan saja. Di samping itu, masyarakat Minangkabau yang bukan ahli bahasa juga merasa bahwa BMk itu tidak banyak bedanya dengan BM sehingga jika orang Minangkabau menggunakan kata BMk dalam berbahasa BM, mereka merasa seperti telah menggunakan kata BM tanpa perlu berusaha mencari kata yang lebih sesuai dalam BM. Banyak sarjana juga menyatakan bahwa kedua bahasa tersebut merupakan satu rumpun bahasa yang sama, yaitu rumpun bahasa Melayu-Polinesia atau yang sekarang ini lebih dekenal sebagai rumpun bahasa Austronesia. Moussay (1998: 12) menyebutkan tentang kedekatan BM dengan BMk sebagai berikut ini.

"Di wilayah Nusantara itu sendiri, bahasa Minangkabau muncul sebagai bahasa yang 
mirip dengan bahasa Melayu, sedemikian dekatnya sehingga para peneliti pertama di abad yang lalu, seperti Marsden ataupun $P$. Favre menganggapnya sebagai dialek Melayu yang dibedakan dari bahasa Melayu oleh beberapa varian leksikan dan fonetis."

Kedua, BMk tidak mempunyai tradisi tulisan, tradisi tulisan dimiliki oleh masyarakat Minangkabau dapat dikatakan relatif baru. Pengenalan terhadap tradisi tulis sejalan dengan pengenalan melalui ejaan Arab-Melayu. Oleh karena itu, dalam bahasa tulis, masyarakat Minangkabau cenderung menggunakan BM.

Ketiga, adanya kecenderungan mengindonesiakan kata-kata yang berasal dari BMk, kemudian menganggap dirinya telah berbahasa Indonesia, sampai sekarang dapat dilihat dalam masyarakat Minangkabau. Nama tempat seperti Tabiang, Lubuak Bagaluang, Padang Laweh, Alang Laweh, Limapuluh Koto dan Kubu Karambia, masing-masing diindonesiakan menjadi Tabing, Lubuk Begalung, Padang Lawas, Alang Lawas, Lima Puluh Kota dan Kubu Kerambil.

Di samping kebahasaannya, dari segi aksara yang digunakan pun juga menarik, yakni penggunaan aksara Jawi. Di dunia Melayu, tidak diketahui kapan pertama kali penggunaan aksara Jawi. Akan tetapi, jelas aksara ini tercipta dan digunakan setelah terjadi pertemuan dunia Melayu dengan agama Islam. Paling tidak aksara Jawi sudah dipergunakan pada akhir abad ke-14 dan awal abad ke-15. Pada waktu itu Kerajaan Melaka diislamkan dengan masuk Islamnya Raja Melaka-Parameswara-bergelar Megat Iskandar Syah. Ia merupakan raja Kerajaan Melaka pertama yang memeluk agama Islam yaitu sekitar 1400 M. Setelah itu, kesusatraan Melayu-Islam berkembang pesat. Kesusastraan Melayu-Islam itu, kemudian, diterjemahkan ke dalam berbagai bahasa di Nusantara. Sejak itu pula dunia Melayu selalu disandingkan dengan Islam sehingga yang disebut Melayu apabila memiliki tiga ciri: berbahasa Melayu, berbudaya Melayu, dan beragama Islam.

Penggunaan aksara Jawi terus berkembang pesat selama berabad-abad untuk berbagai bidang kehidupan yang menggunakan tulisan, tak semata-mata dalam bidang kesusastraan. Pada 1850 Raja Ali Haji membakukan aturan ejaan aksara Jawi dalam kitabnya Bustanulkatibin, di samping berisi tata-bahasa bahasa Melayu.

Dalam masyarakat Melayu-Indonesia pemakaian ejaan Jawi baru terhentiutamanya dalam naskah cetakan-sampai awal abad ke-20. Peranannya digantikan oleh ejaan yang menggunakan aksara Latin. Penulisan bahasa Melayu dengan aksara Latin dimulai pada tahun 1901 yaitu ketika Ch. A. van Ophuysen dibantu oleh Engku Nawawi gl. St. Makmur dan M. Taib St. Ibrahim menerbitkan Kitab Logat Melajoe, yang merupakan pedoman ejaan Latin resmi pertama untuk bahasa Melayu di Indonesia.

Untuk kasus Minangkabau, banyak ditemukan naskah yang ditulis dengan menggunakan aksara Jawi dan sebagian kecilnya dengan aksara Arab dan Latin. Hal ini membedakan dengan skriptorium di wilayah lain yang banyak menggunakan aksara daerah setempat. Hal ini dikarenakan Minangkabau tidak mempunyai aksara. Meskipun ada pendapat yang menyatakan bahwa ada kemungkinan aksara-aksara Sumatera berasal dari Sumatera bagian Tengah dan kemungkinan Minangkabau. Hal ini disebabkan karena aksara yang terdapat di Sumatera mempunyai model dasar yang sama. Akan tetapi, ke Utara memperlihatkan pengembangan yang berbeda dengan pengembangan di bagian Selatan. Masingmasing, baik di Utara dan di Selatan memperlihatkan pengembangan dengan model yang sama. 
Akan tetapi, anehnya tidak ada peninggalan bertulis yang menggunakan "aksara Minangkabau". Hal ini diperkirakan bahwa peninggalan itu mungkin pernah ada, tetapi sudah musnah karena waktu dan proses alam. Ada juga kemungkinan bahwa kemusnahan tersebut disebabkan dengan adanya gerakan pemurnian Islam yang terjadi di Minangkabau. Segala sesuatu yang dipandang tidak Islam dihancurkan, termasuk tulisan itu. Tentang persoalan ini, Kozok (1999: 65-66) mengungkapkan seperti berikut ini.

"Di antara aksara-aksara Nusantara yang paling dekat dengan aksara Batak adalah aksara Kerinci, Rencong, dan Lampung ... Salah satu budaya asing adalah masuknya agama Islam. Serentak dengan penyebaran agama Islam, bersebar pula tulisan Arab yang di Melayu dikenal dengan tulisan Jawi. Aksara "Arab-Gundul" tersebut cepat menggantikan aksara-aksara Sumatera asli yang kemudian hilang sama sekali. ... Besar kemungkinan aksara Minangkabau dan Melayu juga pernah ada tetapi kemudian digantikan oleh tulisan Arab-Melayu sehingga hilang tak berbekas."

Untuk aksara Jawi sendiri, dari beberapa catatan sarjana, seperti Suryadi (2004: 4) menyebutkan bahwa aksara Jawi dikenal luas di Minangkabau pada abad ke18, dan kemudian disusul dengan pengenalan aksara Latin. Dengan dikenalnya kedua aksara tersebut, maka khasanah sastra lisan Minangkabau banyak dituliskan. Penulisan dengan aksara Jawi di Minangkabau semakin berkurang pada akhir abad ke-20. Hal ini dimungkinkan karena tulisan tersebut tidak lagi dikenali oleh banyak orang. Khalayak luas lebih mengerti dan paham dengan aksara Latin.

Hingga akhir abad ke-20 banyak cerita-cerita lisan di Minangkabau yang disalin dan dicetak dengan menggunakan aksara Lain. Meskipun aksara Jawi sudah jarang digunakan di wilayah ini, tetapi aksara tersebut masih bertahan dan digunakan hingga sekarang. Hal ini seperti yang dilakukan oleh kalangan tarekat Syattariyah. Beberapa syaikh nya banyak menulis teks ajaran tasawuf dan sejarah para syaikh tarekat Syattariyah yang seluruhnya menggunakan aksara Jawi.

\section{Simpulan}

Dari fenomena kebahasaan dalam penulisan naskah-naskah Minangkabau membuktikan bahwa dalam berkomunikasi secara tertulis, masyarakat Minangkabau cenderung menggunakan BM. Mungkin dapat pula dikatakan bahwa dalam berkomunikasi secara tertulis, masyarakat Minangkabau tidak mempunyai tradisi menulis dengan menggunakan $\mathrm{BMk}$, tetapi memilih menggunakan BM.

Dalam transliterasi naskah (edisi teks) naskah-naskah Minangkabau ke BM terletak pada dua hal yang saling berhubungan, yaitu, pertama pada tingkat kemudahan transliterasi, dan yang kedua terletak pada tingkat keterbacaannya. Transliterasi ke BM akan dihadapkan pada hambatan rata-rata sebesar 22,23 persen pada setiap halaman naskah. Artinya, katakata ini tidak dapat ditransliterasikan ke BM. Oleh karena itu, transliterasi ke BM akan menghasilkan teks yang sulit dimengerti baik oleh masyarakat berbahasa Melayu maupun oleh masyarakat berbahasa Minangkabau.

Alternatif kedua-sekaligus untuk mengatasi kelemahan-kelemahan yang terdapat pada kemungkinan transliterasi ke BM-adalah transliterasi ke BMk. Kata-kata 
yang menjadi penghambat transliterasi ke bahasa ini hanya berkisar 1 persen pada setiap naskah yang ditulis dengan menggunakan aksara Jawi. Hal ini terutama berlaku pada naskah-naskah kaba. Dengan demikian maka teks yang diperoleh dapat dengan mudah dipahami oleh masyarakat (berbahasa) Minangkabau, yaitu masyarakat tempat cerita ini ditemukan. Namun demikian, usaha transliterasi (menghasilkan edisi teks) ini harus diiringi terjemahan ke dalam bahasa Indonesia (jika dimaksudkan untuk pembaca yang lebih luas bagi masyarakat Indonesia) dan ke dalam bahasa Inggris (jika dimaksudkan untuk pembaca dalam skala internasional).

\section{Ucapan Terima Kasih}

Penelitian ini dibiayai oleh Direktorat Riset dan Pengabdian Masyarakat Direktorat Jenderal Penguatan Riset dan Pengembangan Kementerian Riset, Teknologi, dan Pendidikan Tinggi sesuai dengan Kontrak Penelitian Nomor: 050/SP2H/LT/DPRM/2018 tahun Anggaran 2018.

\section{Daftar Pustaka}

Akhimuddin, Yusri. 2007. "Pemetaan Naskah-naskah Keagamaan di Padang Pariaman". Laporan Penelitian. Batusangkar : STAIN Batusangkar.

Behrend, T.E. 1998. Katalog Naskah-Naskah Nusantara Jilid 4. Jakarta: Yayasan Obor Indonesia-Ecole Francaise D'Extreme Orient.

Brakel, L.F. 1975. The Hikayat Muhammad Hanafiyyah. Bibliotheca Indonesica 12. The Hague: Martinus Nijhoff.

Djamaris, Edwar. 1982. "Bahasa Melayu Minangkabau" dalam Dewan Bahasa, Jurnal Pembinaan dan Pengembangan Bahasa. Jilid 26, bilangan 5, (Mei).
Kuala Lumpur: Dewan Bahasa dan Pustaka Malaysia.

Djamaris, Edwar. 1991 Tambo

Minangkabau: Suntingan Teks

Disertasi Analisis Struktur. Jakarta: Balai Pustaka.

Iskandar, T. 1959. "De hikajat Atjeh" dalam VKI No. 26.

Iskandar, Teuku, 1999, Catalogue of Malay, Minangkabau, and South Sumatran Manuscripts in the Netherlands, I-II, Leiden: Documentatiebureau IslamChristendom.

Junus, Umar. 1959 . "Beberapa Tjatatan tentang Transkripsi Bahasa Minangkabau" dalam Bahasa dan Budaja, Madjalah Ilmiah Populer. Thn. VIII, No. 1 (Oktober). Djakarta: Lembaga Bahasa dan Budaja Fakultas Sastra Universitas Indonesia.

Juynboll, H.H. 1899. Catalogus van de Maleische en Sundaneesche Handschriften der Leidsche Universiteit - Bibliotheek. Leiden: E.J. Brill.

Katkova, Irina R. \& Pramono. 2008. "Endangered Manuscripts of Western Sumatra: Collections of Sufi Brotherhoods". Laporan Penelitian. London : British Library.

Kozok, Uli, 1999, Warisan Leluhur: Sastra Lama dan Aksara Batak, Jakarta: EFEO dan Kepustakaan Populer.

Medan. Tamsin. 1981. "Bahasa Minangkabau, di Sebelah atau di Bawah Bahasa Melayu?: Suatu Studi Pendahuluan Berdasarkan Penelitian Dialektologis" dalam Bahasa dan Sastra. Thn. VII Nomor 3. Jakarta: Pusat Pembinaan dan Pengembangan Bahasa.

Moussay, Gérard, 1998, Tata Bahasa Minangkabau, Diindonesiakan oleh Rahayu S. Hidayat, Jakarta: Perpustakaan Populer Gramedia.

Muhardi. 1986. "Kritik dan Edisi Teks Kaba si Tungga". (Tesis untuk gelar 
Magister Sains Program Pendidikan Master Pascasarjana Universitas Pajajaran Bandung).

Pramono, 2010, "Direktori Penelitian Naskah di Minangkabau", dalam Filologi dan Islam Indonesia (Oman Fathurahman dkk.), Jakarta: Puslitbang Lektur Keagamaan, Depag. Pramono. 2009. "Surau dan Tradisi Pernaskahan Islam di Minangkabau: Studi Atas Dinamika Pernaskahan di Surau-surau di Padang dan Padang Pariaman". Artikel dalam Jurnal Studi Islamika HUNAFA Vol. 6 No. 3 Hlm. 265-290.

Ricklefs, M.C. dan P. Voorhoeve. 1977. Indonesia Manuscripts in Great Britain. Oxford: Oxford University Press.

Roesli. 1967. Pengadjaran Bahasa Minangkabau. Djakarta: Bhratara.

Ronkel, Ph. S. Van. 1909 . "Catalogus der Maleische Handschriften in het Museum van het Bataviaasch Genootschap", VBG deel LVII. Batavia: Albrecht \& Co.

Roolvink, R. 1965 . "The Passive-Active =er/Ber-/Per-/Memper Correspondence in Malay". Lingua 25. HIm. 310-337.

Suryadi. 2004. Syair Sunur: Teks dan Konteks Otobiografi Seorang Ulama Minangkabau Abad Ke-19. Padang : Citra Budaya.

Sutaarga, Amir dkk. 1972. Katalogus Koleksi Naskah Melayu Museum Pusat Dep. $P \& K$. Jakarta: Proyek Inventarisasi dan Dokumentasi Kebudayaan Nasional Direktorat Jenderal Kebudayaan.

Tim Peneliti Balai Bahasa Padang bekerja sama dengan Fakultas Sastra Unand. 2009 "Penelusuran Naskah di Kota Sawahlunto dan Kabupaten Sijunjung", Laporan Penelitian. Padang : Balai Bahasa Padang.
Toorn, J.L. van der. 1899. Minangkabausche Spraakkunst. 's-Gravenhage: Martinus Nijhoff.

Wan Mamat, Ali Haji. 1985. Katalog Manuskrip Melayu di Belanda (Catalogue of Malay Manuscripts in the Netherlands). Kuala Lumpur: Perpustakaan Negara Malaysia.

Wieringa, E. P., 1998, Catalogue of Malay and Minangkabau Manuscripts in the Library of Leiden University and Other Collections in the Netherlands, (vol. 1), Leiden: Legatum Warnerianum in the Library of the University of Leiden.

Yusuf, M. (Penyunting). 2006. Katalogus Manuskrip dan Skriptorium Minangkabau. Tokyo : Centre for Documentation and AreaTranscultural Studies, Tokyo University of Foreign Studies.

Zuriati dan M. Yusuf. 2008. "The Digitisation of Minangkabau's Manuscript Collections in Suraus". (Laporan Penelitian pada Programme Endangered, British Library, London).

Zuriati, 2007, Undang-Undang Minangkabau dalam Perspektif Ulama Sufi, Padang: Fakultas Sastra Universitas Andalas. 